\title{
エネルギ -*
}

丹生慶四 郎**

Key words: recycle energy, fossil fuel, sun energy, atomic energy, nuclear fission energy, nuclear fusion energy.

\section{1. 人間とエネルギー}

\section{1 再生可能なエネルギー}

我々人間は地球上で，人間の生活を中心に据光，他の 動植物は人間生活に利用するためにあるもののごとく振 舞っているが，どうして人間はかく万物に君臨出来るよ らになったのであろらか．人間を他の動物から区別する 言葉は沢山ある.「人は笑う動物である」といらのがある が，この言葉は今の主題とは関係がない。「人は考光る 蕫である」といらのは，確かに良い言葉である．むちろ ん一つの事象が，ただ一つの原因に帰着出来れば明確で 気持ちも良いが，大抵は多くの原因㴆因していたり， 一言で述べた理由が多面からの集約的表現であることが 多い、「人は火を使う動物である」といら言葉は, 科学 技術上は非常に重要であって，ここで強調しておきたい 言葉である．動物は火を恐れるが，人間は火を手中に入 れて，動物から身を守り，暖を取って凍觉を逃れ，また 食物の調理に利用してきた。言いかえれば，人間は火を 通じてェネルギーを積極的に人間の生活手段に取り入れ た唯一の動物ということになる，我々のまわりをみてわ かるように，人間の使っているエネルギーの源は，石炭 や石油を燃やすといった燃焼熱を利用していることが大 半で，まさに「火」で代表されるわけである，人間の人 間たるゆえんが火を利用してきたこと，つまりは土ネル ギーを生活手段に繰り入れてきたことであってみると， 生活の中でェネルギーの消費を減らすのは, 人間の本性 に反することであって，なかなか実行し難いと思らので ある。

エネルギーの単位に $\mathrm{Q}$ とらのがあって, $1 \mathrm{Q}=10^{18}$ B.T. U. (British Thermal Unit) $=1.05 \times 10^{21} \mathrm{~J}$ とい ら大きな単位である.人間の毎年使用するエネルギー量 は紀元 0 年から 1850 年ころまでほぼ一定で, 年間あた り $0.004 \mathrm{Q}$ ぐらいであったと推定されている1).この間, 人は山で薪を採ったり，炭を焼いたり，菜種油を採取し たりしてェネルギー源を確保していた。これらの薪や炭 は, また翌年樹が成長してェネルギー源を提供するので, 再生可能なエネルギーと呼ぶ. 人間が再生可能なエネル

* 原稿受付 昭和 57 年 9 月 7 日.

** 東京工業大学大学院 (横浜市緑区長津田町 4259)
ギーのみを使用する限りでは，人間社会にェネルギー問 題は生まれずにすんだわけである. 紀元 0 年から 1850 年ころまでは, 科学, 技術の進歩はなかったので, 人間 は輪廻の世界に埋没していたことになる。これを幸せと 思うのはエネルギーの恩恵の中に身を置く文明人の感傷 であって, 事実はそうではない, 人々は疫病の蔓延に対 してなすすべなく徒死してゆき, 少数の富裕階級という 強者の生活が, 多数の貧乏人という弱者の労役の上に築 かれていた時代である。

\section{2 化石燃料}

18 世紀から 19 世紀にかけて、イギリスを中心に産業 革命が起こり, 機械力が人間の労力に代わって下辺の人 達を苦役から解放するとともに, 産業は家内労働から工 場労働へ手工業的少数生産から大量生産へと移行寸るき っかけが生まれることになる。しかしまだ産業革命の初 期に执いては, 肉体労働に代わるエネルギー源は風力で あったり水力であったりした，風力も水力も炭や薪之同 様に地球に与える太陽の恵みに起因するもので, やはり 再生可能なエネルギーである. 1781 年, James Wattが 蒸気機関のピストンの往復運動を回転運動に換兄る装置 を発明し, 蒸気発生の然料に石炭が用いられるに及んで, 再生可能なェネルギー利用の輪廻の世界は終焉を告げる のである。石炭や石油は，太古に太陽エネルギーを吸収 して成長した植物の死骸であって, いわば太古の太陽エ ネルギーの缶詰であり，もとよりその量は有限であって, 再生可能なェネルギー源ではない，もっとも現在でも森 林資源で人類が利用しているのは $1 \%$ 程度で, 残りの 99 \%は未利用のままであるが，これらが新たに石炭や石油 に変化することはなく，無駄に朽ち果てているに過ぎな い. 人間が再生不可能なェネルギーである化石燃料（石 炭, 石油) の使用法を知るに及几で, 急速にエネルギー の使用量は增加し, 紀元 0 年から 1850 年 までの 年平均 $0.004 \mathrm{Q}$ の使用エネルギーに対して, 紀元 1850 年より 1950 年の過去 100 年では, 使用エネルギーは1けたあが って年平均 $0.04 \mathrm{Q}$ 飞達している.これが 1950 年より 2050 年の今後 100 年にわたって考光れば, 年平均のエネ ルギー使用は更に 1 けた上昇するであ万ら。近年エネル ギー源は石炭から石油に急速に切り換兄られたが，これ は石炭が使用しつくされたからではなく, 石油や天然ガ 
スが石炭に比べてよりクリーンでより便利であるからで 五。，商業的に成り立つ範囲で採掘可能な石炭の埋蔵量 はエネルギーにして約 $100 \mathrm{Q}$, これに対して不油の埋蔵 量は $30 \mathrm{Q}$ 程度と推定されている2). 目下の全人類の年

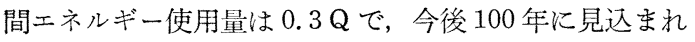
る必要エネルギーは70Qである。このエネルギー使用 は現在著しく先進国に集中している. エネルギーの使用 量を增加し，より快適な生活を持ちたいと希望するのは 人間の本能に近い欲望であるから，今後先進国が多少は 省エネルギーに努力しても, 発展途上国のエネルギー使 用量の増加に伴らエネルギー問題は避けては通れない. 今後 100 年の人類のエネルギーを不油のみで賄いきれな い事実は，すでに石油が自㥉争の市場から離れて，産 油国による独占価格に支配されつつある現象に実証され ている.

石油で代表される 20 世紀のエネルギ一源は, 燃焼と いう化学エネルギーを利用していることになる。しかし 薪や木炭といった再生可能なエネルギーは, 現在の大型 エネルギー消費に対して無視し得る程度の役にしか立ち 得ないし, 再生不可能な化石然料の総量も有限であって, 今後 100 年間これのみに頼ると社会混乱を引き起こすこ とは必至である。したがって人類が今の文明路線を引き ついで混乱なく生存発展を続けるためには, この 100 年 以内に新エネルギー源を開発することが是非とも必要に なってくる。

\section{3 太陽エネルギー}

エネルギーの総量として大きいのは太陽エネルギーで ある. 太陽から出るエネルギーのらち, 地球に降り注ぐ のは極くごく一部で, これまで我々の祖先も太陽エネル ギーを農業等に利用してきたわけであるが，今後化石然 料に代わって大量消費エネルギー源として文明の支光手 になり得るであろらか. 太陽は $1 \mathrm{~s}$ 当たり $9.3 \times 10^{21} \mathrm{kcal}$ $\left(\fallingdotseq 3.9 \times 10^{23} \mathrm{~J}\right)$ のエネルギーを放出しており，そのらち 地球へ届くのは 10 億分の 5 の $4.1 \times 10^{13} \mathrm{kcal} / \mathrm{s}(\fallingdotseq 1.7 \times$ $1017 \mathrm{~J} / \mathrm{s}$ ) である.これを 1 年分積算すると $1.3 \times 10^{21} \mathrm{kcal}$ $=5 \times 10^{3} \mathrm{Q}$ となり, 人類が仮に 1 年 $1 \mathrm{Q}$ 使ったとしても 5000 年分のエネルギーに相当するくらい大きい. 全地 球的に見ると人の使うェネルギー量は, 降り注ぐ太陽エ ネルギーに比べて微々たるものだといらことになる。た だ太陽エネルギーの密度は低く，途中吸収などないとし て, 太陽光線に垂直な地上面に届く太陽エネルギーは 2 $\mathrm{cal} /\left(\mathrm{cm}^{2} \cdot \mathrm{s}\right)\left(\fallingdotseq 8 \times 10^{4} \mathrm{~J} /\left(\mathrm{m}^{2} \cdot \mathrm{s}\right)\right)$ でる. 太陽エネル ギーがこの程度低密度であるために, 大量のエネルギー を集めるためには広い面積を必要とするなど，概して密 度の低いエネルギーは利用し難いものである.エネルギ 一を発生させる装置を作るとき，科学技術的にだけ考え
ても(経済性ももらろん重要であるが), エネルギー増幅 率が 1 を越さねば意味を持たない。ここで装置のエネル ギー増幅率を

エネルギー増幅率

装置の寿命中に装置より取り出し得る全エネルギー 装置を製作するに要したエネルギー

で定義しておくことにする．装置の寿命はよく20 年と 選ばれる．分母は例えば鉄鉱石を搬出し，精鍊し，鉄材 にし，運搬し，加工し，装置に組み立てるまでに必要な 一切のエネルギーを加えなければならないし，然料の必 要な装置では, 燃料の採掘, 運搬, 灰の処理等のエネル ギーも含む．また大エネルギー源になるためには 1 個の 装置だけでは不足であって，装置を増加していかねばな らないから，1台の装置から 20 年間に最低 1 個の活かの 装䁂の製作分のエネルギーを余分に供給する必要がある として，分母に2をかける計算法がよく採用される，密 度の低いエネルギーを利用する装置では, 装置は大型化 し分母のエネルギーが大きくなるので, 增幅率はなかな か 1 を越し難い.太陽エネルギーのように密度の低いエ ネルギーを利用する場合, 比較的低温で使い得る方法が 好ましい. 暖房には例えば水温を $40^{\circ} \mathrm{C}$ 程度に温め得れ ば利用出来るし, 冷房に使用するためには水温は $75^{\circ} \mathrm{C}$ 以上必要である.太陽ェネルギーをこれら低温熱源とし て利用する場合でも, 装置のエネルギー増幅率は 1 を越 乙難い, 発電等高温 (火力発電で $1400^{\circ} \mathrm{C}$, 原子力発電 で $800^{\circ} \mathrm{C}$ 程度)を必要とする場合に利用しようとすれば なおさらである、太陽を始め自然エネルギーはエネルギ 一密度が低いので, まだ大エネルギー源として利用し得 る目処が立っていないのが実情である。

\section{2. 原子カエネルギー}

\section{1 特殊相対性理論と原子カエネルギー}

1905 年Albert Einstein は特殊相対性理論を提案し た3).ニュートンが提唱した古典力学によると, 質量, 運動量, エネルギーといった古典力学の基本的変量は変 化の前後でそれぞれ別個に保存されることになっている が，特殊相対論ではそうではなく，互いに関連を持って いることになる，例えば物体の全ェネルギーEは，その 物体の静止質量 $m_{0}$ と

$$
E=m_{0} c^{2} / \sqrt{1-v^{2} / c^{2}}
$$

で結ばれている. 上式で $c$ は真空中の光速, $v$ は物体の 速さである. 物体の質量 $m$ はもはや一定ではなく, 物 体の速さ $v$ と

$$
m=m_{0} / \sqrt{1-v^{2} / c^{2}}
$$

で結ばれているといらのが特殊相対性理論の主張であ る. 式(1)でvをcに比べて小さいとして根号の中を展 
開すると，

$$
E=m_{0} c^{2}+\left(\frac{1}{2}\right) m_{0} v^{2}
$$

と書ける. 右辺第 2 項は古典力学における運動エネルギ 一で我々にはなじみのものである. 右辺第 1 項は速度に よらず一定であるが，静止質量 $m_{0}$ を含んでいるので, 質量とエネルギーは独立に保存するものではなく, 相関 関係を持つことを知るのである．もし $m_{0}$ の質量が突然 消えてなくなったとすると， $m_{0} c^{2}$ に等しいエネルギー が発生していなければならないことになる. 光速 $c$ は大 きな值を持つので, 質量から変化したエネルギー量は非 常に大きなものとなり，例えば $1 \mathrm{~kg} の$ 質量は $9 \times 10^{16} \mathrm{~J}$ に相当して，1 人の人間が生涯に使用する全ェネルギー を上回る量である．物質の質量の大半は原子核が担って いて，電子は極く軽いものであるので，質量をエネルギ 一に変換するとすれば原子核の質量を減少させることに なる，この原子核の質量の減少を利用して得られるエネ ルギーを，原子力ェネルギーという．原子力ェネルギー は1945 年，広島と長崎へ投下された原子爆弾で実証さ れたのは不幸なことであったが，現在は発電用のエネル ギー源として使用されるなど平和目的にも利用されてい る.

\section{2 原子核の安定性}

さてここで原子核をもら少し立ち入って調べてみよ う. 原子核は更に素粒子と呼ばれるより基本的な粒子か ら構成されている．素粒子は現在多くの種類が発見され ているけれども, 電子, 陽子, 中性子が最も基本的な素 粒子である. 電子は質量 $9.109 \times 10^{-31} \mathrm{~kg}$, 電荷 $-1.6 \times$ 10-19 Cで，原子核のまわりを回っているが，原子核は 質量 $1.673 \times 10^{-27} \mathrm{~kg}$, 電荷 $1.6 \times 10^{-19} \mathrm{C}$ の陽子女質量 $1.675 \times 10^{-27} \mathrm{~kg}$ で電気的に中性の中性子から構成され ている．陽子と中性子とは一括して核子と呼ばれること がある. 水素原子は 1 個の陽子からなる原子核のまわり を 1 個の電子が回っている. ヘリウムは 2 個の陽子と 2 個の中性子を持つ原子核のまわりを 2 個の電子が取りま いている，そこでへリウムを例にとると，原子核を ${ }_{2}^{4} \mathrm{He}$ のように書く。ヘリウム原子核は 4 個の核子からなり， そのらち陽子は 2 個である. 原子記号の左上の数字は原 子核を構成する核子の数，すなわち質量数を表し，左下 の数字は原子核を構成する陽子の数，すなわち原子番号 を表すものとする。

中性子は電気的に中性であるが，陽子は正の電荷を持 っている. 同種の電荷間にはクーロン力と呼ばれる反発 力が働くことはよく知られている. いま電荷 $q_{1}, q_{2}$ の同 種の電荷を持つ質点が距離 $\boldsymbol{r}$ 離れて置かれているとき, 質点間に働くクーロン力を $F$ とすると， $F$ は

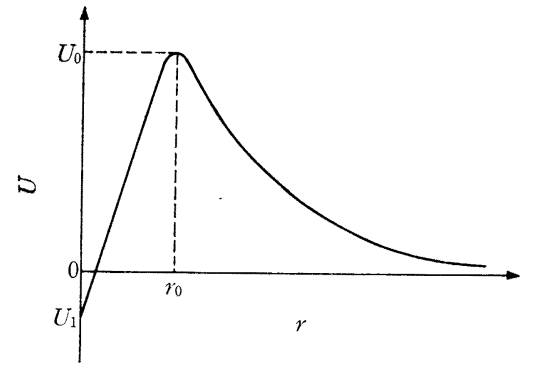

図 1 陽子間のクーロン力と核力のポテンシャル

$F=q_{1} q_{2} / 4 \pi \varepsilon r^{2}$

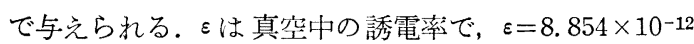
$\mathrm{F} / \mathrm{m}$ である. 二つの質点が無限に遠ざかったときを基 準として, 距離 $r$ まで接近したとき持つ質点の位置エネ ルギーUは

$$
U=-\int_{\infty}^{r} q_{1} q_{2} / 4 \pi \varepsilon r^{2} \cdot \mathrm{d} r=q_{1} q_{2} / 4 \pi \varepsilon r
$$

で与えられる.両質点を陽子であるとし $\left(e=1.6 \times 10^{-19} \mathrm{C}\right.$ として $\left.q_{1}=q_{2}=e\right), r$ として原子核の半径 $r_{0}=5 \times 10^{-15}$ $\mathrm{m}$ を選ぶと, $U$ は $U_{0}=0.29 \mathrm{MeV}$ となる.ここで $\mathrm{eV}$ と は，陽子又は電子が $1 \mathrm{~V}$ の電位差で加速されたとき得る 運動エネルギーのことで $1.602 \times 10^{-19} \mathrm{~J}$ に等しく, 素粒 子や原子核の運動エネルギーを表す単位としてょく用い られる．核子間の距離が $5 \times 10^{-15} \mathrm{~m}$ ぐらいより小さく なると,核子間には核力と呼ばれる強い引力が作用する。 この核力が原子核を構成する陽子, 中性子を核内に安定 に結びつけているわけである.クーロン力と核力をあわ せて陽子間のポテンシャルェネルギーUと距離 $\boldsymbol{r}$ との関 係を図示すると図 1 のようになる。 づくにつれてクーロン力によるポテンシャルエネルギー が増加し， $r_{0}$ の内側では引力の核力が働くので，ポテン シャルエネルギーは減少していることを示している，r $=0$ での $U$ の值 $U_{1}$ が負であることは，クーロンポテン シャルより核力のポテンシャルの方が大きいことを意味 し，二つの陽子が $r=\infty$ で別個に存在するよりも結合し て一つの原子核を構成している方が安定である，以上は 二つの質量が陽子である場合について考えたが，電荷が それぞれ $q_{1}=Z_{1} e, q_{2}=Z_{2} e$ の三つの原子核の場合はど らであろらか.クーロン力は $F=Z_{1} Z_{2} e^{2} / 4 \pi \varepsilon r^{2}$ となる が，核力の作用し始める距離 $\boldsymbol{r}_{0}$ や榜力自身はあまり原 子核の電荷数 $Z$ には依存しない。したがって, 原子核間 のポテンシャルェネルギーUは図 2 のようになり,クー ロンカのポテンシャルエネルギーによる $U_{0}{ }^{\prime}$ の值は図 1 の $U_{0}$ の $Z_{1} Z_{2}$ 倍となるが，他方核力によるポテンシ ヤルエネルギーによる值 $U_{0}{ }^{\prime}-U_{1}{ }^{\prime}$ は $U_{0}-U_{1}$ とあまり 変わらないので, $Z_{1} Z_{2}$ がかなり大きいと $U_{1}{ }^{\prime}$ は正とな 


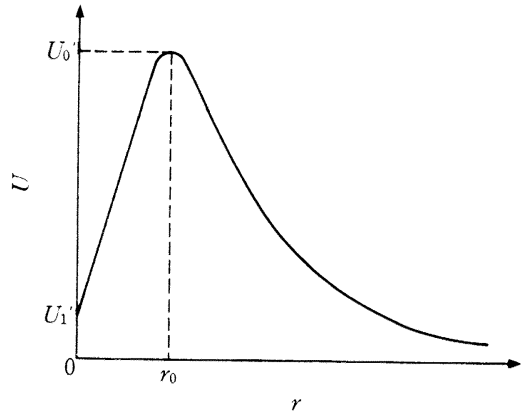

図 2 大きな $Z$ を拈つ原子核間のクーロン力と核力の ポテンシャル

る。このよらな場合は，二つの核は合体して一つの大き な核を形成するより，二つの小さな核に分かれた方が安 定である，以上を総合すると，大きい原子核は二つ以上 の核に分裂した方が安定であり，小さい原子核は融合し て大きい一つの原子核を形成した方が安定であることが わかる.ちょうど $Z=26$, 寸なわち鉄のあたりがその境 界にある原子で，最も安定な原子核を構成していること になる。

\section{3 核分裂エネルギー}

ウランは最も大きな原子核を持つ原子で，原子核は不 安定である. 中性子は電荷を持っていないので容易に原 子核に接近することができ，もし原子量 235 を持つウラ ンの原子核に吸収されると, 核は不安定になって核分裂 を起こす，典型的な核分裂反応を式で示すと

$$
{ }_{92}^{235} \mathrm{U}+{ }_{0}^{1} \mathrm{n}=2 \times{ }_{50}^{118} \mathrm{Sn}+8 \mathrm{e}+236 \mathrm{MeV}
$$

と書ける。 ${ }_{0}^{1} \mathrm{n}$ は中性子, $\mathrm{e}$ は ${ }_{-1}^{0} \mathrm{e}$ と書くべきであろらが 電子を表す，核反応方程式では，反応の前後で原子番号 の和 (陽子の数) と原子量の和 (中性子と陽子の数) は両 辺で等しくなっている. ${ }_{92}^{235} \mathrm{U}$ は原子量 235. 124 (1 原子量 $=1.6603 \times 10^{-27} \mathrm{~kg}$ ), すなわち原子核の質量は3.903 764 $\times 10^{-25} \mathrm{~kg}$, すず ${ }_{50}^{118} \mathrm{Sn}$ の原子量は 117.94 で, 原子核の質 量は $1.958158 \times 10^{-25} \mathrm{~kg}$ である. したがってウランの原 子核と中性子の質量の総和と，2 個のすずの原子核の質 量との差は $4.201 \times 10^{-28} \mathrm{~kg}$ である。これは原子核反応 による質量の減少量 (質量欠損)であり，式 (3) に従って これをェネルギーに換算すると $3.78 \times 10^{-11} \mathrm{~J}=236 \mathrm{MeV}$ となる. 現在のウランを利用する原子力発電などでは, この核分裂による原子力エネルギーを利用しているわけ である。

昭和 31 年我が国では東海村の日本原子力研究所で輸 入の第一号炉 JRR-1 が臨界に達した時,「我が国にも第 二の火がともりました」とアナウンサーが実況のラジオ 放送で述べていたのを思い出す，然焼を第一の火とする
ならば，確源子力は人間が新しく手にした第二の火 である.現在主として軽水炉の形で利用している原子力 エネルギーは, ウランの核分裂を用いるわけであるが, ウ ランの埋蔵量（富鉱のみを対象にして）は $2.5 \times 10^{10} \mathrm{~kg}$ 程度である. 天然のウランは ${ }_{92}^{235} \mathrm{U}$ と ${ }_{92}^{228} \mathrm{U}$ の同位体が混 合しており，このらち核分裂を起こすので軽水炉で然料 として使用できる ${ }_{92}^{235} \mathrm{U}$ は約 $0.7 \%$ しか存在しない. ${ }_{92}^{235} \mathrm{U}$ の核分裂で発生するエネルギーを電力に変換する際，炉 の安全性を高めるために比較的低温で师を運転して熱効

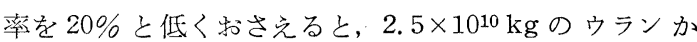
ら得られる電力はたかだか 7Qといらことになってしま ら。遠くない将来人類のエネルギー使用量が年 $1 \mathrm{Q}$ に達 するであるらことを考えると，折角人間が手にした第二 の火である原子力にも余り多くを期待し得ないと，がっ かりする.ただ核分裂を起こさない ${ }_{92}^{2 \varepsilon} \mathrm{U}$ は高速の中性子 を吸収すると，

$$
{ }_{92}^{228} \mathrm{U}+{ }_{0}^{1} \mathrm{n} \rightarrow{ }_{92}^{239} \mathrm{U} \rightarrow{ }_{93}^{239} \mathrm{~Np} \rightarrow{ }_{94}^{239} \mathrm{Pu}
$$

なる核反応を経て，核分裂を起こすプルトニウムに変換 される. ${ }_{92}^{228} \mathrm{U}$ を ${ }_{92}^{235} \mathrm{U}$ と一緒に燃焼して ${ }_{94}^{239} \mathrm{Pu}$ に変換する 原子炉を高速增殖炉と呼んでいる。この際然料の増殖率 $\left({ }_{92}^{238} \mathrm{U}\right.$ より ${ }_{94}^{239} \mathrm{Pu}$ への変換率) を60\% とし，をた炉材料 や炉構造の改良により安全性が向上して原子炉の熱効率 が将来 30\%に高められたとすると, ウランによる原子 カエネルギーとして $300 \mathrm{Q}$ が期待されることになる．ウ ランを有効利用するためには高速増殖炉の完成が待たれ る（我が国では原子炉「もんじゅ」が建設中であり，フ ランスでは電力 120 万 $\mathrm{kW}$ の商業炉スーパーフェニッ クスが 1984 年完成する)ゆえんであり，また使用済み燃 料から未燃烍のウランとプルトニウムを回収する燃料サ イクルの確立が実現されなければならない、污染物質お よび炭酸ガスを大気へ拡散させてしまう火力発電に比べ て, 原子力は放射線を含む核分裂生成物（特にプルトニ ウムは猛毒であり，容易に原子爆弾も作り得る）を炬心 の然料棒の中に閉じ込め得るといら利点は大いにある が，この大量の，また長期にわたる放射性生成物を完全 に処理することが(利用法も開発しなければならない), 核分裂原子力に課せられた技術的重要問題である.

\section{3. 核融合エネルギー}

\section{1 重水素の融合反応}

太陽は半径 $7 \times 10^{8} \mathrm{~m}$, 質量 $2 \times 10^{30} \mathrm{~kg}$ の巨大な球体 で, 毎秒 $9.3 \times 10^{21} \mathrm{kcal}\left(\fallingdotseq 3.9 \times 10^{25} \mathrm{~J}\right)$ のエネルギーを 放出し，地上に熱と光を送り届けてくれている．もし太 陽が石炭で出来ていてこの放出エネルギーが石炭の燃焼 熱でまかなわれているとすると，巨大とはいえ太陽の石 
炭は 3000 年で然え尽きてしまうことになる. 菖の人は， どらして太陽がいつまでも然え続けているのか不思議で 仕方がなかった. Einstein が特殊相対性理論を提案する に及んで，我々はやっとそのからくりを知るに及んだの である。

水素の原子核は一つの陽子のみからできているので, 融合して大きな原子核になった方が安定である．もし

$$
4{ }_{1}^{1} \mathrm{H}+2 \mathrm{e}={ }_{2}^{4} \mathrm{He}+27.05 \mathrm{MeV}
$$

という原子核反応が起こったらどうであろらか. 水素の 原子量は 1.008 , ヘリウムの原子量は 4.003 であるので, 約 $0.7 \%$ すなわち $4.815 \times 10^{-29} \mathrm{~kg}$ の質量欠損を生じ, $4.3334 \times 10^{-12} \mathrm{~J}=27.05 \mathrm{MeV}$ のエネネ゙ー放出を伴う ことになる.太陽はこの核融合反応のエネルギーによっ て輝き続けているのであり，この反応による限り 50 億 年間で太陽はその質量の 3000 分の 1 減少するに過ぎな いことがわかるのである.

もし地上でも(8)の反応が利用出来れば非常に好都合 である，水素はいくらでもあるし，反応生成物としてで きるへリウムは安定した気体で, 利用価值こそあれ無害 である、けれどもこの反応率は至って小さく，巨大な天 体である太陽であってこそ，小さな反応率でも大きなエ ネルギーを放出し得るわけであるが，地上のちっぽけな 発電所からェネルギーを取り出すことは不可能である. 地球上の水中には重量比にして $1 / 5000$ 重水素 $\left({ }_{1}^{2} \mathrm{H}\right.$ であ るが特に D または ${ }_{1}^{2} \mathrm{D}$ で表す）を含んでいる。この重水 素は

$$
{ }_{1}^{2} \mathrm{D}+{ }_{1}^{2} \mathrm{D}=\left\{\begin{array}{l}
{ }_{2}^{3} \mathrm{He}+{ }_{0}^{1} \mathrm{n}+3.27 \mathrm{MeV} \\
{ }_{1}^{3} \mathrm{~T}+{ }_{1}^{1} \mathrm{H}+4.03 \mathrm{MeV}
\end{array}\right.
$$

という核融合反応をほぼ等確率で行う． ${ }_{1}^{3} \mathrm{~T}$ は三重水素 又はトリチウムと呼ばれ，Dとともに水素の同位体であ る. (9) の反応は (8) の反応に比べて反応率はずっと高い. 式 (9)の核融合反応ェネルギーは, 風呂桶 1 杯の重水(重 水 $\mathrm{D}_{2} \mathrm{O}$ が $\left.1 \mathrm{t}\right)$ で, 人が一生で利用するエネルギー $(2 \times$ $1016 \mathrm{~J})$ をまかなえる量で，核融合エンジンを積んだ自動 車なら, 石油缶 1 杯の重水で一生以上乗りまわせること になる. 地上には水が $10^{20} l$ 存在するので, これから重 水素を抽出して核融合反応の然料に使用したとすると, 得られる融合エネルギーは $7.5 \times 10^{9} \mathrm{Q}$ に達する。これ は 100 億年間の人類のエネルギーをまかなら量であるか ら，この核融合エネルギーが利用できるとすれば，まず エネルギー問題は解決したことになる，核融合反応は式 (9)で与えられたものに限定はされないから，核融合を人 間の手中にするといらことは極めて重要な意味を持って いる.つまり人間がェネルギー問題から解放され得るか
ぞうかの境目を決める魔法である。だからこそ神は人間 にそれ程たやすく魔法箱を手渡してはくれず，人々は今 生みの苦しみを味わっている最中である。エネルギ一問 題は決して単なる科学技術上の問題のみではない. 社会 科学の発展は今でも自然科学の急速な発展に比べてギャ ップがあるように感じられるが，エネルギー問題は近く は食糧問題に絡及, 南北問題, 国際問題等, 経済・社会 問題を通じて社会科学自体に影響を及ぼし，人間の考え 方にも基本的な变革をもたらして人文科学にも波及する 程の一大問題である.

\section{2 総合科学技術としての核融合}

地上で核融合エネルギーを利用するためには，式 (9) で与えられるDD 反応でもかなりむずかしく，目下はよ り実現の簡単なDT反応

$$
{ }_{1}^{2} \mathrm{D}+{ }_{1}^{3} \mathrm{~T}={ }_{2}^{4} \mathrm{He}+{ }_{0}^{1} \mathrm{n}+17.6 \mathrm{MeV}
$$

を利用することが試みられている. 重水素は天然の水の 中に重量比で $1 / 5000$ 存在するので, 水中から摂取する ことができる．式(10)の反応を起こさせるためには三重 水素が是非必要であるが, 三重水素は半減期 12 年で $\beta$ 崩填する放射性物質で, 天然には存在しない,リチウム を用いて次の反応で生成する。

$$
\begin{aligned}
& { }_{3}^{6} \mathrm{Li}+{ }_{0}^{1} \mathrm{n}={ }_{2}^{4} \mathrm{He}+{ }_{1}^{3} \mathrm{~T}+4.8 \mathrm{MeV} \\
& { }_{3}^{7} \mathrm{Li}+{ }_{0}^{1} \mathrm{n}={ }_{2}^{4} \mathrm{He}+{ }_{1}^{3} \mathrm{~T}+{ }_{0}^{1} \mathrm{n}-2.47 \mathrm{MeV}
\end{aligned}
$$

すなわち DT 反応で, 真の然料はりチウムと重水素であ ることがわかる. 三重水素は $\beta$ 崩壊する放射性物質であ るが, 放射エネルギーは小さく影響は小さいと思われる. ただ水素の同位体であるために, 酸素と結合して水を作 る. 三重水素を含む水を飲むと, 水は体内に永く滞留す るので, $\mathrm{T} よ り$ 出る $\beta$ 線が生殖器官に影響を及ぼす可能 性がある。漏洩しやすい水素の同位体であるが，Tを用 い，をたは $\mathrm{T}$ を生成する核融合反応を利用する場合， $\mathrm{T}$ を厳重に管理することが重要な問題になってくる。

Li は鉱山資源として採取されるが，鉱床は偏在し，ア メリカ, カナダ, アフリカが主たる産地であって, 核融 合でも，この限り我が国は資源国ではあり得ないＬi 推定埋蔵量はあまり明確ではないが，900 万 $\mathrm{t}$ 程度と推 測される，これを式(10)で示すDT反応の燃料に用いた

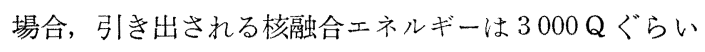
である. 海水中には Li は $0.17 \mathrm{ppm}$ 含まれており, これ を回収できれば $6 \times 10^{6} \mathrm{Q}$ のエネルギーに相当する. 海 水中の重水素は $158 \mathrm{ppm}$ で, その抽出は比較的容易で, すでにプラントも稼動しているが，海水中には Li と分 離困難な元素 $\mathrm{Na}, \mathrm{K}, \mathrm{Ca}, \mathrm{Mg}, \mathrm{Br}$ などが多く含まれてい るため, 経済的にも採算に乗る $\mathrm{Li}$ の分離技術を確立する 
ことが我が国には必要である（海水中には色 色な元素が含まれており，ウランも 0.0033 $\mathrm{ppm}$, 総量で 44 億 $\mathrm{t}$ 存在し，これが利用でき るならば核分裂の燃料も鉱山資源のUを上 まわり，我が国も資源国となり得る)。

式(10)中の $\mathrm{D}$ \& $\mathrm{T}$ も水素の同位体で，これ が融合して He になるためには, 図 1 中の $U_{0}$ $=0.29 \mathrm{MeV}$ のクーロンポテンシャルの山を 乗り越えなければならない。このポテンシャ ルの山を乗り越えるだけのエネルギーをD やTに与光る方法としては，太陽にならっ て D と T の混合気体を熱して，その熱エネ ルギーを利用することが考えられている。で はどれくらいの温度まで熱すれば, Dや $\mathrm{T}$ の 原子核がポテンシャルの山を越せるかといら 之, 大体 1 億 $\mathrm{K}$ が目安である. 1 回の DT 核 融合反応から出るェネルギーは $17.6 \mathrm{MeV}=$ $2.82 \times 10^{-18} \mathrm{~J}$ で至って少量であるので, 我々 が核融合エネルギーを利用するためには一度 にかなり大量の反応を起こさねばならない。 反応個数は $\mathrm{D}$ や $\mathrm{T}$ の数密度 $n$ の 2 乗に比例 するので, 高温の DT ガス(電離しているの でプラズマと呼ぶ）はかなり高密度でなけれ ばならないＤTTプラズマの高温・高密度状 態がまた最低ある時間間隔にわたって持続し なければェネルギーは取り出せないから，持 続時間 $\tau$ も重要である. DT プラズマの数密度 $n$ と, 高 温·高密度の持続時間 $\tau$ の積 $n \tau$ は核融合パラメータと呼 ばれて，核融合ェネルギーを取り出すためには，口ーソ ン条件と呼ばれる $n \tau>10^{15} \mathrm{~s} / \mathrm{cm}^{3}$ を満たさなければな らない。

太陽は重力で高温プラズマを保持しているが，地上で $10^{8} \mathrm{~K}$ もの高温プラズマを保持する材料はないので，保 持の方法で，磁界閉じ込め方式之慣性閉じ込め方式に大 別して研究が進められている4). 磁界閉じ込め方式は $n$ $=1015 / \mathrm{cm}^{3}$ 程度のプラズマを $1 \mathrm{~s}$ 程度磁界で保持しょう とする方式で，代表的な実験装置にトカマクと呼ばれる ものがある. 図 3 がトカマクの模式図, 図 4 がその横断 面図を示す． $T=10^{8} \mathrm{~K}, n=1015 / \mathrm{cm}^{3}$ の DT プラズマを 閉じ込めるためには磁界は $7 T$ の強度が必要で, 常伝導 コイルで磁界を発生させたとすると、コイルを励磁する ための電力は核融合で得られる電力を上回るとも言われ る程である。したがって是非とも超伝導コイルを使用し な姑ればならない，超高温のプラズマと極低温の超伝導 コイルが同居して，核融合実験装置は正に先端技術の集 合体である．DT 反応で発生するエネルギー $17.6 \mathrm{MeV}$

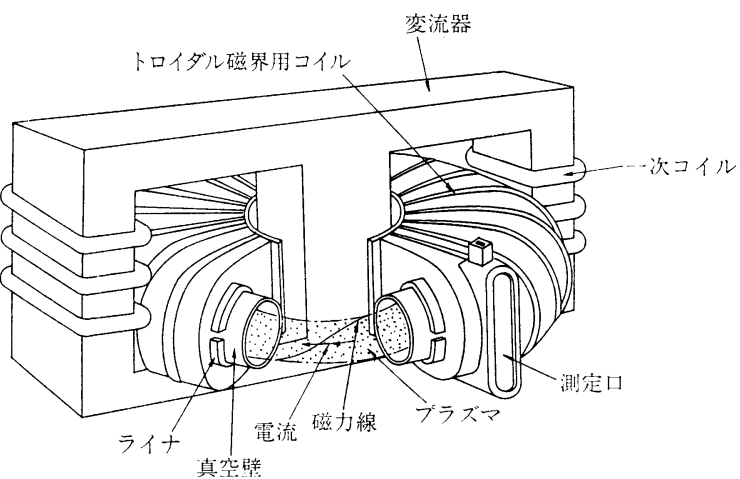

図 3 トカマク見取図

電力系統

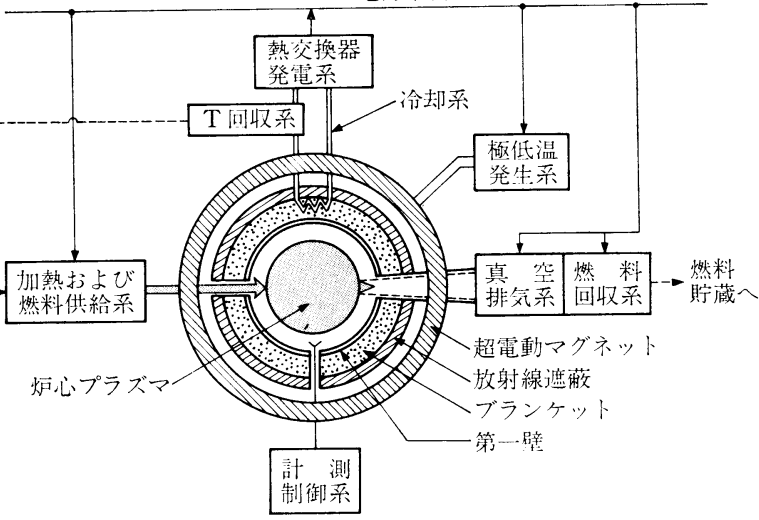

図 4 トカマク断面図

のらち，4/5の $14.1 \mathrm{MeV}$ は中性子の運動エネルギーと して放出される．図4 のプラズマ中で発生した中性子は まず第一壁を通過するが，第一壁の金属原子核とぶつか って，スパッタリング，ブリスタリング，スウェリング を起こし，材料を劣化させる。また，

$$
\begin{aligned}
& { }_{a}^{b} \mathrm{X}+{ }_{0}^{1} \mathrm{n}={ }_{a-1}^{b} \mathrm{Y}+{ }_{1}^{1} \mathrm{H} \\
& { }_{a}^{b} \mathrm{X}+{ }_{0}^{1} \mathrm{n}={ }_{a-2}^{b-3} \mathrm{Z}+{ }_{2}^{4} \mathrm{He}
\end{aligned}
$$

によってXから核変換で生じた原子 Y あるいは Z が放 射性で，炉材に大量の誘導放射能を作り出す可能性があ り, 処理上由由しき問題となり得るものである. 誘導放 射能の小さい高温材料として, 金属や七ラミックの新核 融合炉材の開発が必要である.

中性子の運動エネルギーは, ブランケット部で熱とし て回収されねばならない, 冷却材としては, 式(11) ある いは式 (12) で三重水素 Tを增殖する必要上, 液体金属の $\mathrm{Li}$ ，あるいはりチウム化合物 $\mathrm{LiPb}$, フライベ ( $\mathrm{LiF}$ と $\mathrm{BeF}_{2}$ をモル比で $2: 1$ 飞混合したもの) 等が利用される. 燃料の $\mathrm{T}$ は $\mathrm{Li}$ より作られねばならぬから， $\mathrm{T}$ の增殖率 は 1 を上回らねばならず，また液体 $\mathrm{Li}$ または $\mathrm{Li}$ の化合 
物から Tを漏洩させることなく分離回収する技術を確 立する必要がある．冷却材としての $\mathrm{Li}$ 等はひとまず $\mathrm{Na}$ と熱交換し, 高速增殖炉で培われた技術を基礎に再び水 と熱交換して, 蒸気タービンを回して発電する予定であ る. Li は活性の強い原子であり, 炉材あるいは熱交換 材として Li と両立性のよい安全な材料を選ぶことが要 求される.

磁界閉じ込め方式では, 超高温プラズマのまわりを超 伝導コイルが交錯し, 炉構造が極めて複雑となって設計 が不可能とならないかとまで言われている. そこで磁界 に代わって慣性でプラズマを閉じ込める，慣性閉じ込め 方式が新しく提案されている，慣性でプラズマを保持で きる時間は $\tau=10^{-8} \mathrm{~s}$ と極めて短いので, ローソン条件 を満たすためには DT プラズマの数密度は $n=10^{23} / \mathrm{cm}^{3}$ と高くなければならない. 半径 1〜10 mm の DT 球を冷 凍して固体にし（固体密度は $n_{s}=5 \times 10^{22} / \mathrm{cm}^{3}$ ), この球 にまわりから $10^{-8} \mathrm{~S}$ の短時間に, イオンビーム, 電子ビ ーム、レーザ等により 1〜10 MJ のエネルギーを注入し て, DT 然料を加熱 $\left(T>10^{8} \mathrm{~K}\right)$ 圧縮 $\left(n>10^{26} / \mathrm{cm}^{3}\right)$ 乙 て核融合反応に導くのである, 慣性核融合の場合, 装置 内に磁界用コイルは必要ないので，第一壁を炉心のプラ ズマから遠ざけることができ，また第一壁の内面に液体
Li を流して, 中性子のエネルギーを液体 Liに吸収し, 第一壁の損傷を軽減できる可能性が高い。しかし慣性に よるプラズマの保持時間の短さから, 慣性閉じ込め方式 では核融合炉はいきおいパルス運転とならざるを得ず, 炉壁は熱および圧力衝撃にさらされることになる.

核融合はまさに科学技術の総合結集の上に進められる 大事業で, 道は険しい. またトリチウム (三重水素) の 管理, 誘導放射能の軽減と処理という問題は残るけれど も, 核融合は核分裂と異なり, 暴走の心配はなく, 反応 生成物に強力な放射性物質を作らない.エネルギーの総 量はけた違いに大きく，この完成によって，人間生活に 対する一つの大きな制約を取り除くことになるのであ る. 新しい倫理に基づく新しい世界の㖪生につながると 言って，あえて過言ではないと信じるものである.

\section{文献}

1) P.Putunam: エネルギー問題の将来, 商工出版 (1953).

2) 日本AES 機構: WAES レポート, 世界のエネルギーの 将来, 1980 2000, 共立出版 (1978).

3) A.Einstein: Relativity, The Special and General Theory, Henry Holt, New York, N. Y., (1920).

4）丹生慶四郎，杉浦 賢：核融合，共立出版 (1982).

\section{編 集 後 記}

技術は両刃の剣などと言われる．歴史的にそれは事実 だったし，現在でもそう考学られる事件は多くある。し かし，この言葉は，技術を作り出していくもの，技術者 にとっては, 技術の結果についての責任が技術の外にあ るといら規定であって, 責任逃がれといら面がある. 編 集委員会でこのような問題提起があり，1年以上続いた 議論は有益なものであったが，むずかしいテーマで本特 集号は難産であった．技術の現場で仕事をする我々が， 自己の問題として今までを反省し，未来の技術に責任を 持ちたい.これは一般技術評論でなく, 学会員による学 会に関係の深い分野からの発言として論じられるのでな
ければならない。一方，技術の外からの批判と見直しを， 我々に語りかけてくれる論文が欲しい，精機学会に関連 の深い問題として, 経済, 産業, 労働などが考えられる. この分野については，大河内一男教授にご推薦をいただ き，その他編集委員が知恵を絞って作ったのがこの企画 である．執筆者の方々は我々の趣旨をよく理解いただい て, 予期以上の特集になった. 大河内先生はじめ, 執筆 者の方々に心から感謝したい. 技術者の責任は今後ます ます大きくなるだろう。一人ひとりが深く考えることは もちろん重要だが, 学会でこの視点を確立していくこと も必要なことだと思われる。

(吉川弘之) 